\title{
Preliminary Assays Indicate that Antonia ovata (Loganiaceae) and Derris amazonica (Papilionaceae), Ichthyotoxic Plants Used for Fishing in Roraima, Brazil, Have an Insecticide Effect on Lutzomyia longipalpis (Diptera: Psychodidae: Phlebotominae)
}

\author{
José Francisco Luitgards-Moura, Eloy Guillermo Castellón Bermudez*, Arnaldo Felisberto \\ Imbiriba da Rocha**, Pantelis Tsouris, Maria Goreti Rosa-Freitas/***/+
}

Núcleo Avançado de Vetores do Instituto Oswaldo Cruz-Fiocruz, Centro de Ciências Biológicas e da Saúde, Universidade Federal de Roraima, BR 174 s/nº, 69310-270 Boa Vista, RR, Brasil *Instituto Nacional de Pesquisas da Amazônia, Manaus, AM, Brasil

**Departamento de Química, Universidade do Amazonas, Manaus, AM, Brasil ***Departamento de Entomologia, Instituto

Oswaldo Cruz-Fiocruz, Rio de Janeiro, RJ, Brasil

Laboratory-reared Lutzomyia longipalpis (Lutz and Neiva 1912) was tested with extracts of two ichthyotoxic plants, known as timbós, used as fishing poison in the Amazon. Phlebotomines, L. longipalpis, and plants, Antonia ovata and Derris amazonica, were collected in the Raposa-Serra do Sol Indian Reserve, a focus of visceral leishmaniasis in the State of Roraima, Brazil. Extracts were prepared from dried leaves of A. ovata and roots of D. amazonica that were percolated in water, filtered and dried out at $50^{\circ} \mathrm{C}$. The solid extract obtained was diluted in water at 150, 200 and $250 \mathrm{mg} / \mathrm{ml}$. The solution was blotted in filter paper placed at the bottom of cylindric glass tubes containing sand flies. For each plant extract and dilution, two series of triplicates with 5 male and 5 female specimens of $\mathrm{L}$. longipalpis were used. Mortality was recorded every $2 \mathrm{~h}$ during $72 \mathrm{~h}$ of exposure. At $72 \mathrm{~h}$ the mortality was as high as $80 \%$ for extracts of A. ovata $\left(L D_{50}=233 \mathrm{mg} / \mathrm{ml}\right)$, and $100 \%$ for $\mathrm{D}$. amazonica $\left(L D_{50}=212 \mathrm{mg} / \mathrm{ml}\right)$ whereas in the control groups maximum mortality never surpassed 13\%. Preliminary assays indicated that A. ovata and D. amazonica displayed significant insecticide effect against $\mathrm{L}$. longipalpis.

Key words: ichthyotoxic extract - timbó - natural insecticides - Lutzomyia longipalpis - Derris amazonica - Antonia ovata Roraima - Brazil

Visceral leishmaniasis is considered to be a zooanthroponosis formerly restricted to rural and periurban areas in Brazil. Lately, visceral leishmaniasis has assumed an important role in public health due to the emergence of foci of the disease in urban areas (Marzochi \& Marzochi 1994). Besides being the main visceral leishmaniasis vector in Brazil, Lutzomyia longipalpis can be a nuisance, as flies can bite at any time and at high densities (Quinnel \& Dye 1994). Leishmaniasis transmission occurs mainly in the peridomicile although can also occur in the extradomicile (Lainson et al. 1985). Even though insecticide spraying is not routinely used for phlebotomine control, it has been used in situations where important peri- and intradomiciliary transmission prevailed (Marzochi \& Marzochi 1994, Pereira \& Fonseca 1994). The peridomestic vectors of Leishmania, Phlebotomus papatasi (in the Old World) and L. longipalpis and $L$. intermedia (in the New World) have been controlled by intradomiciliary insecticide spraying (Falcão et al. 1991, López-Antuñano 1992).

This work was partially supported by Capes (MSc scholarship to JFLM) and by the Government of Roraima.

${ }^{+}$Corresponding author. Fax: +55-21-2573.4468. E-mail: goreti@hotmail.com

Received 31 August 2001

Accepted 19 February 2002
Crude plant extracts and inorganic larvicides were largely used as natural insecticides before the organic laboratory synthesized insecticides became available in the 1940 decade (Balandrin et al. 1985, Raws 1986, WHO 1997). In fact, natural insecticides have been used for centuries to combat insect pests that compete for food and that affect public health (WHO 1997). Plant extracts such as pyrethrum, nicotine and rotenone were among the first compounds used to control insects of agricultural importance (Grainge \& Ahmed 1988). Pyrethrins, a complex of esters extracted from flowers of Chrysanthemum cinerariefolium, are still used nowadays to enhance commercial preparations of household insecticides (Bell et al. 1990). Nicotine extracted from Nicotiana glauca and its nicotinoids derivatives are choice molecules for the manufacture of new insecticides. Rotenone and rotenoids are isoflavonoids occurring in several genera of tropical leguminosae plants such as Derris (Papilionaceae), Antonia (Loganiaceae) and Lonchocarpus (Fabaceae). There have been reports of rotenone-containing plants used by Indians to fish due to its ichthyotoxic effect, as early as the 17th century (Biet 1664 apud Moretti \& Grenand 1982). Rotenoids have strong paralysis action on coldblooded animals. For mammalians lethality tests resulted in $\mathrm{LD}_{50}$ as low as $25 \mathrm{mg} / \mathrm{kg}$ (Raws 1986). Rotenoids are also reported to have an insecticide effect against the tobacco budworm Heliothis virescens (Lepidoptera: Noctuidae; Yoshida \& Toscano 1994). Rotenoid-yielding plants have being used for fishing based on their ichthyotoxic properties. 
Ichthyotoxicity is indeed an attribute distributed among a wide range of species. Mangrove Euphorbiaceae and Sapindaceae plants and umbellifer (Teixeira et al. 1984, Van Wagenen et al. 1988, Miles et al. 1989), dinoflagellates (Igarashi et al. 1999), cyanobacterium (Berman et al. 1999), blue-green and red tide algae (McCoy \& Martin 1977, Igarashi et al. 1998), nudibranch and dictyoceratide sponge (McPhail et al. 1998) are among those reported as producing ichthyotoxins. Ichthyotoxicity, and insecticide activity for some of these species, make them of potential interest for use in agriculture, aquaculture and animal husbandry (Reinertaen et al. 1987, Johnson et al. 1988).

Ichthyotoxic plants are known in Brazil under the generic denomination of timbó. The utilization of ichthyotoxic plants among native Amazonian Indians (Maiongong/ Ye'kuana, Wapixana, Macuxi and Sanumá ethnic groups; Farabee 1918, Smith 1939) has been done mainly as a fishing method. Timbós are in fact plants of many genera and species. Usually, roots of Derris sp. and Tephrosia sp. (Leguminosae) and leaves of A. ovata and Phyllanthus brasiliensis are broken and macerated with the aid of stones in wooden pestle and mortar. The macerated material is squeezed on partially blocked river streams, or lakes, giving off a white milky liquid with a characteristic smell. The previous downstream blockage use sticks of bamboo or guarumã (Ischnosiphon aruma) to increase effectiveness and retain the drugged fish. Interestingly, rotenone poisoned fish is edible without any risk of food contamination to humans (Costa et al. 1989). Others species of common use include $D$. utilis (timbó-macaquinho), $D$. игиси (timbó-иrиси), Tephrosia toxicaria (timbó-decaiena). D. amazonica is locally known as ailá and $A$. ovata as timbózinho (Angely 1985). A. ovata is widely distributed among fields and savannas of Brazil, but their use for fishing is restricted to the State of Roraima.

Previous ichthyotoxic effect studies showed that the mechanism of insecticide action is not well understood and seems to be ubiquitous for insects. D. elliptica and D. uliginosa from Fiji showed insecticide activity (Mors et al. 1973). Purified rotenones from the roots of Derris and Lonchocarpus are used as insecticides (Sukamar et al. 1991). Triatomines exposed to extracts of D. urucu showed a mortality of $90-100 \%$ with a residual action up to 6 months (Klocke 1989). D. urucu and D. nicou also tested positive against lice and larvae of Musca domestica (Costa et al. 1989, 1997).

In the literature there has been no report on the effects of D. amazonica and A. ovata on insects.

The aim of this study was to verify the insecticide effect on L. longipalpis of A. ovata and D. amazonica, common ichthyotoxic plants used for fishing by indigenous people in Roraima.

\section{MATERIALS AND METHODS}

Collection areas - Plant and L. longipalpis phlebotomine specimens were collected in the localities of Maloca da Malacacheta $02^{\circ} 40^{\prime} 11^{\prime \prime} \mathrm{N}, 60^{\circ} 27^{\prime} 21^{\prime \prime} \mathrm{W}$ (roots of $D$. amazonica Killip, Papilionaceae) and Maloca do Napoleão $03^{\circ} 55^{\prime} 04^{\prime \prime} \mathrm{N}, 60^{\circ} 01^{\prime} 44^{\prime}$ 'W (leaves of A. ovata Pohl, Loganiaceae), an endemic leishmaniasis area located in the Raposa-Serra do Sol Indian Reserve, Roraima, Brazil. Macuxi and Wapixana Indian ethnical groups mainly form local population. This endemic visceral leishmaniasis area is located in the Normandia municipality $\left(03^{\circ} 52^{\prime} 52^{\prime} \mathrm{N}\right.$, $59^{\circ} 37^{\prime} 22^{\prime \prime} \mathrm{W}, 100 \mathrm{~m}$ ). The region is formed by savanna, with a tropical humid climate and maximum rainfall of 1,600 mm in June (Ministério das Minas e Energia 1975).

L. longipalpis specimens were collected and bred in colony, maintained at $26 \pm 2^{\circ} \mathrm{C}$ and $86 \%$ relative humidity (Luitgards-Moura et al. 2000).

Plants and extraction - Specimens of timbó were collected together with individuals of the Macuxi and Wapixana communities. Plants were identified to species by Dr Aldaléa Sprada Tavares (Instituto Nacional de Pesquisas da Amazônia-Inpa, Manaus). Roots of $D$. amazonica and leaves of $A$. ovata were crushed in water to obtain extracts. Leaves and roots were allowed to dry in the shade, at room temperature $\left(30^{\circ} \pm 5^{\circ} \mathrm{C}\right)$, crushed, weighted and submitted to extraction with hot water in a coffee maker (1 1 capacity, Walita). Five liters of water were used to percolate $300 \mathrm{~g}$ of either roots or leaves (60 $\mathrm{g} / \mathrm{l})$. Infusion was filtered and water allowed to evaporate slowly by heating the extract at $50^{\circ} \mathrm{C}$ in a Pyrex glass dish on a hot plate ( $48 \mathrm{~h}$ average). Residue was weighed, scratched with spatula, transferred to a grail, crushed and placed in sealed jars in the refrigerator $\left(16^{\circ} \mathrm{C}\right)$.

Bioassays - L. longipalpis specimens were placed in glass vials with $5 \times 8 \mathrm{~cm}$ filter papers blotted with different extract concentrations previously wet with distilled water and allowed to dry out overnight at room temperature. Filter papers were then placed at the bottom of the glass bottles and specimens transferred into them. A piece of gauze was used to close the bottle. To feed phlebotomines a piece of cotton, wet with 5\% glucose solution, was placed on the gauze. Two triplicate series with 5 specimens of $L$. longipalpis were used for each plant extract (roots of $D$. amazonica and leaves of $A$. ovata $)$ and dilution (150, 200 and $250 \mathrm{mg} / \mathrm{ml}$ ). The first triplicate series contained 5 males in each vial and the second triplicate series contained 5 females in each vial. Therefore, 30 specimens were assayed for each plant extract and dilution. Negative controls used the same schedule. Males and females were not tested together. A total of 180 specimens was assayed (Tables I, II).

Bottles containing males and females were placed in three separated plastic boxes according to dilution with a piece of wet filter paper at the bottom to keep moisture. Mean lethal dosage, designated as $\mathrm{LD}_{50}$, was determined at $12,24,36,48$ and $72 \mathrm{~h}$ of exposition. Acute toxicity was expressed by the necessary amount in $\mathrm{mg}$ of product per body weight to promote death of $50 \%$ of specimens. $\mathrm{LD}_{50}$ was calculated using the Polo program (Russel et al. 1977).

\section{RESULTS}

The $\mathrm{LD}_{50}$ was $233 \mathrm{mg} / \mathrm{ml}$ for A. ovata and $212 \mathrm{mg} / \mathrm{ml}$ for D. amazonica at $48 \mathrm{~h}$ of exposure. Apparently, $L$. longipalpis females were more affected by D. amazonica extracts, while males seem to be more affected by $A$. ovata. At $72 \mathrm{~h}$, exposition to $D$. amazonica $(250 \mathrm{mg} / \mathrm{ml})$ resulted in $100 \%$ female mortality, opposed to $60 \%$ for A. ovata (Figs 1,2). Male exposition to A. ovata $250 \mathrm{mg} / \mathrm{ml}$ extract resulted in $80 \%$ mortality, opposed to $66.7 \%$ for $D$. amazonica, at $72 \mathrm{~h}$ (Figs 1,2). Curiously, A. ovata at 150 
TABLE I

Number (and percentage) of dead specimens of Lutzomyia longipalpis exposed to extracts of the timbó Derris amazonica at different concentrations (150, 200 and $250 \mathrm{mg} / \mathrm{ml}$ ) expressed as cumulative values. Triplicates of five male (M) and five female (F) specimens were tested for each extract and concentration

\begin{tabular}{|c|c|c|c|c|c|c|c|c|c|c|c|c|}
\hline \multirow{3}{*}{ Time (h) } & \multicolumn{12}{|c|}{ Number of specimens dead } \\
\hline & \multicolumn{2}{|c|}{ Control (\%) } & \multicolumn{2}{|c|}{$150 \mathrm{mg}(\%)$} & \multicolumn{2}{|c|}{ Control (\%) } & \multicolumn{2}{|c|}{$200 \mathrm{mg}(\%)$} & \multicolumn{2}{|c|}{ Control (\%) } & \multicolumn{2}{|c|}{$250 \mathrm{mg}(\%)$} \\
\hline & M & $\mathrm{F}$ & M & $\mathrm{F}$ & M & $\mathrm{F}$ & M & $\mathrm{F}$ & M & $\mathrm{F}$ & M & $\mathrm{F}$ \\
\hline & 0 & 0 & 0 & 0 & 0 & 0 & 0 & 0 & 0 & 0 & 0 & 0 \\
\hline & 0 & 0 & 0 & 0 & 0 & 0 & 0 & 0 & 0 & 0 & 1 & 1 \\
\hline & 0 & 1 & 0 & 2 & 0 & 0 & 0 & 0 & 0 & 0 & 1 & 1 \\
\hline \multirow[t]{4}{*}{12} & 0 & $1(6.6)$ & 0 & $2(13.3)$ & 0 & 0 & 0 & 0 & 0 & 0 & $2(13.3)$ & $2(13.3)$ \\
\hline & 0 & 0 & 0 & 0 & 0 & 0 & 2 & 1 & 0 & 0 & 0 & 0 \\
\hline & 0 & 0 & 0 & 1 & 0 & 0 & 1 & 0 & 0 & 0 & 1 & 0 \\
\hline & 0 & 0 & 1 & 0 & 0 & 1 & 0 & 0 & 0 & 0 & 0 & 0 \\
\hline \multirow[t]{4}{*}{24} & 0 & $1(6.6)$ & $1(6.6)$ & $3(20)$ & 0 & $1(6.6)$ & $3(20)$ & $1(6.6)$ & 0 & 0 & $3(20)$ & $2(13.3)$ \\
\hline & 0 & 0 & 0 & 0 & 0 & 0 & 0 & 0 & 0 & 0 & 1 & 2 \\
\hline & 0 & 0 & 1 & 0 & 0 & 1 & 1 & 0 & 0 & 0 & 1 & 3 \\
\hline & 0 & 0 & 1 & 0 & 0 & 0 & 0 & 0 & 0 & 0 & 1 & 3 \\
\hline \multirow[t]{4}{*}{36} & 0 & $1(6.6)$ & $3(20)$ & $3(20)$ & 0 & $2(13.3)$ & $4(26.7)$ & $1(6.6)$ & 0 & 0 & $6(40)$ & $9(60)$ \\
\hline & 0 & 0 & 1 & 1 & 0 & 0 & 0 & 2 & 0 & 0 & 1 & 1 \\
\hline & 0 & 0 & 0 & 0 & 0 & 0 & 0 & 2 & 0 & 0 & 1 & 1 \\
\hline & 0 & 0 & 0 & 0 & 0 & 0 & 1 & 0 & 1 & 0 & 1 & 1 \\
\hline \multirow[t]{4}{*}{48} & 0 & $1(6.6)$ & $4(26.7)$ & 4 (26.7) & 0 & $2(13.3)$ & $5(33.3)$ & $5(33.3)$ & $1(6.6)$ & 0 & $9(60)$ & $12(80)$ \\
\hline & 0 & 0 & 0 & 0 & 0 & 0 & 0 & 0 & 1 & 0 & 0 & 0 \\
\hline & 0 & 0 & 0 & 0 & 0 & 0 & 1 & 0 & 0 & 0 & 0 & 0 \\
\hline & 0 & 0 & 0 & 0 & 0 & 0 & 0 & 2 & 0 & 1 & 0 & 0 \\
\hline \multirow[t]{4}{*}{60} & 0 & $1(6.6)$ & $4(26.7)$ & $4(26.7)$ & 0 & $2(13.3)$ & $6(40)$ & $7(46.7)$ & $2(13.3)$ & $1(6.6)$ & $9(60)$ & $12(80)$ \\
\hline & 0 & 0 & 1 & 0 & 0 & 0 & 0 & 0 & 0 & 0 & 0 & 2 \\
\hline & 0 & 0 & 1 & 0 & 0 & 0 & 1 & 0 & 0 & 0 & 0 & 1 \\
\hline & 0 & 0 & 0 & 0 & 0 & 0 & 0 & 1 & 0 & 0 & 1 & 0 \\
\hline \multirow[t]{4}{*}{72} & 0 & $1(6.6)$ & $6(40)$ & $4(26.7)$ & 0 & $2(13.3)$ & $7(46.7)$ & $8(53.3)$ & $2(13.3)$ & $1(6.6)$ & $10(66.7)$ & $15(100)$ \\
\hline & 0 & 0 & 2 & 1 & 0 & 0 & 2 & 3 & 1 & 0 & 2 & 5 \\
\hline & 0 & 0 & 2 & 1 & 0 & 1 & 4 & 2 & 0 & 0 & 4 & 5 \\
\hline & 0 & 1 & 2 & 2 & 0 & 1 & 1 & 3 & 1 & 1 & 4 & 5 \\
\hline Total dead & 0 & 1 & 6 & 4 & 0 & 2 & 7 & 8 & 2 & 1 & 10 & 15 \\
\hline
\end{tabular}

$\mathrm{mg} / \mathrm{ml}$ resulted in higher mortality for females than did at higher concentrations, from $36 \mathrm{~h}$ onwards (Fig. 2). Maximum mortality in the control groups did not exceed $13.3 \%$ (Tables I, II).

\section{DISCUSSION}

Notwithstanding the advantageous eco-toxicological properties of natural insecticides and species selectivity and biodegradability, synthetic insecticides have almost completely replaced natural ones as the standard method of controlling detrimental insects, ticks and mites. Control programs for vector transmitted diseases are challenged by the increasing resistance of vectors to insecticides, the increasing costs of insecticides and the need for alternative control methods, including new insecticides (White 1991).

Because of problems arisen with broad insecticide ef- fects, soil and water contamination and resistance, the demand for natural and nonpersistent insecticides increased. Current biotechnology procedures allow the development of engineered plants and plant cell cultures that produce a wide array of insecticide products as part of their secondary metabolism in high amounts.

Natural insecticide products originated from plants have been used since ancient times. Pyrethrum, saponin, nicotine and rotenone, all natural insecticides, have been largely used in pest control for medical and agricultural purposes (Coats 1994). Nowadays more than 2,000 plant species are catalogued as having insecticide properties, including the timbós (Heal et al. 1950, Farnsworth 1966, Sukamar et al. 1991).

Insecticide action of timbó is related to the inhibition of the cellular respiration pathway (Aragão \& Valle 1973). Insects display a decrease on oxygen consumption, on 
TABLE II

Number (and percentage) of dead specimens of Lutzomyia longipalpis exposed to extracts of the timbó Antonia ovata at different concentrations $(150,200$ and $250 \mathrm{mg} / \mathrm{ml})$ expressed as cumulative values. Triplicates of five male (M) and five female (F) specimens were tested for each extract and concentration

\begin{tabular}{|c|c|c|c|c|c|c|c|c|c|c|c|c|}
\hline \multirow{3}{*}{ Time (h) } & \multicolumn{12}{|c|}{ Number of specimens dead } \\
\hline & \multicolumn{2}{|c|}{ Control $(\%)$} & \multicolumn{2}{|c|}{$150 \mathrm{mg}(\%)$} & \multicolumn{2}{|c|}{ Control $(\%)$} & \multicolumn{2}{|c|}{$200 \mathrm{mg}(\%)$} & \multicolumn{2}{|c|}{ Control (\%) } & \multicolumn{2}{|c|}{$250 \mathrm{mg}(\%)$} \\
\hline & M & $\mathrm{F}$ & M & $\mathrm{F}$ & M & $\mathrm{F}$ & M & $\mathrm{F}$ & M & $\mathrm{F}$ & M & $\mathrm{F}$ \\
\hline & 0 & 0 & 0 & 0 & 0 & 0 & 0 & 0 & 0 & 0 & 0 & 1 \\
\hline & 0 & 0 & 0 & 0 & 0 & 0 & 0 & 0 & 0 & 0 & 0 & 0 \\
\hline & 0 & 0 & 1 & 1 & 0 & 0 & 0 & 0 & 0 & 0 & 1 & 0 \\
\hline \multirow[t]{4}{*}{12} & 0 & 0 & $1(6.6)$ & $1(6.6)$ & 0 & 0 & 0 & 0 & 0 & 0 & $1(6.6)$ & $1(6.6)$ \\
\hline & 0 & 0 & 0 & 0 & 0 & 0 & 0 & 1 & 0 & 0 & 0 & 0 \\
\hline & 0 & 0 & 0 & 1 & 0 & 0 & 1 & 1 & 0 & 0 & 1 & 0 \\
\hline & 0 & 0 & 0 & 0 & 0 & 0 & 0 & 0 & 0 & 0 & 0 & 0 \\
\hline \multirow[t]{4}{*}{24} & 0 & 0 & $1(6.6)$ & $2(13.3)$ & 0 & 0 & $1(6.6)$ & $2(13.3)$ & 0 & 0 & $2(13.3)$ & $1(6.6)$ \\
\hline & 0 & 0 & 0 & 1 & 0 & 0 & 1 & 0 & 1 & 0 & 1 & 0 \\
\hline & 0 & 0 & 0 & 1 & 0 & 0 & 0 & 0 & 0 & 0 & 1 & 1 \\
\hline & 0 & 0 & 0 & 1 & 0 & 0 & 0 & 0 & 0 & 0 & 0 & 0 \\
\hline \multirow[t]{4}{*}{36} & 0 & 0 & $1(6.6)$ & $5(33.3)$ & 0 & 0 & $2(13.3)$ & $2(13.3)$ & $1(6.6)$ & 0 & $4(26.7)$ & $2(13.3)$ \\
\hline & 0 & 0 & 1 & 0 & 0 & 0 & 1 & 2 & 0 & 0 & 1 & 0 \\
\hline & 0 & 0 & 1 & 0 & 0 & 0 & 2 & 2 & 0 & 0 & 2 & 2 \\
\hline & 0 & 0 & 1 & 1 & 0 & 0 & 0 & 0 & 1 & 0 & 2 & 4 \\
\hline \multirow[t]{4}{*}{48} & 0 & 0 & $4(26.7)$ & $6(40)$ & 0 & 0 & $5(33.3)$ & $6(40)$ & $2(13.3)$ & 0 & $9(60)$ & $8(53.3)$ \\
\hline & 0 & 1 & 0 & 1 & 0 & 0 & 0 & 0 & 0 & 0 & 0 & 0 \\
\hline & 0 & 0 & 0 & 1 & 0 & 1 & 0 & 0 & 0 & 0 & 0 & 0 \\
\hline & 0 & 0 & 0 & 1 & 1 & 0 & 0 & 0 & 0 & 1 & 0 & 0 \\
\hline \multirow[t]{4}{*}{60} & 0 & $1(6.6)$ & $4(26.7)$ & $9(60)$ & 0 & $1(6.6)$ & $5(33.3)$ & $6(40)$ & $2(13.3)$ & 0 & $9(60)$ & $8(53.3)$ \\
\hline & 0 & 0 & 0 & 0 & 0 & 0 & 0 & 0 & 0 & 0 & 2 & 1 \\
\hline & 0 & 0 & 0 & 0 & 0 & 0 & 1 & 1 & 0 & 0 & 1 & 0 \\
\hline & 1 & 0 & 0 & 0 & 1 & 0 & 1 & 1 & 0 & 0 & 0 & 0 \\
\hline \multirow[t]{4}{*}{72} & $1(6.6)$ & $1(6.6)$ & $4(26.7)$ & $9(60)$ & $1(6.6)$ & $1(6.6)$ & 7 (46.7) & $8(53.3)$ & $2(13.3)$ & 0 & $12(80)$ & $9(60)$ \\
\hline & 0 & 1 & 1 & 2 & 0 & 0 & 2 & 3 & 1 & 0 & 4 & 2 \\
\hline & 0 & 0 & 1 & 3 & 0 & 1 & 4 & 4 & 0 & 0 & 5 & 3 \\
\hline & 1 & 0 & 2 & 4 & 1 & 0 & 1 & 1 & 1 & 0 & 3 & 4 \\
\hline Total dead & 1 & 1 & 4 & 9 & 1 & 1 & 7 & 8 & 2 & 0 & 12 & 9 \\
\hline
\end{tabular}

muscle contraction and finally paralysis when in contact with timbós (Aragão \& Valle 1973). Toxic components belonging to the group of saponins and rotenones have been identified in timbós (Braz Filho et al. 1975). Saponins are phytoglycosides with emulsifying, toxic and hemolytic properties and also have the ability to complex cholesterol (Chacon 1973). Anti-fungicidal, anti-bacterial and abortive properties were also reported for saponins (Mahato et al. 1982, Moretti \& Grenand 1982).

Rotenone is believed to be the main toxic component in timbó species (Derris and Tephrosia, Chacon 1973, Xavier 1975). Separation of rotenoid active products from the raw material could potentialize insecticide effects observed in the extracts.

Our preliminary results indicate that $D$. amazonica and
A. ovata extracts have an insecticide effect on L. longipalpis males and females. Plant-derived substances are sources of potential new insecticides that may play a more prominent role in integrated pest management programs. Besides being candidates as biomolecules of choice for scale-up production, the use of timbós extracts could represent an economically viable way of vector control made by people living in these leishmaniasis endemic areas. D. amazonica and A. ovata are readily available and of common use by the community where visceral leishmaniasis is endemic in Roraima. Extracts are obtained through basic techniques and tools and, can be either sprayed on the walls or fumigated. New control insecticide substances can emerge from traditional popular knowledge bringing a sustainable vector control method in poor areas. 


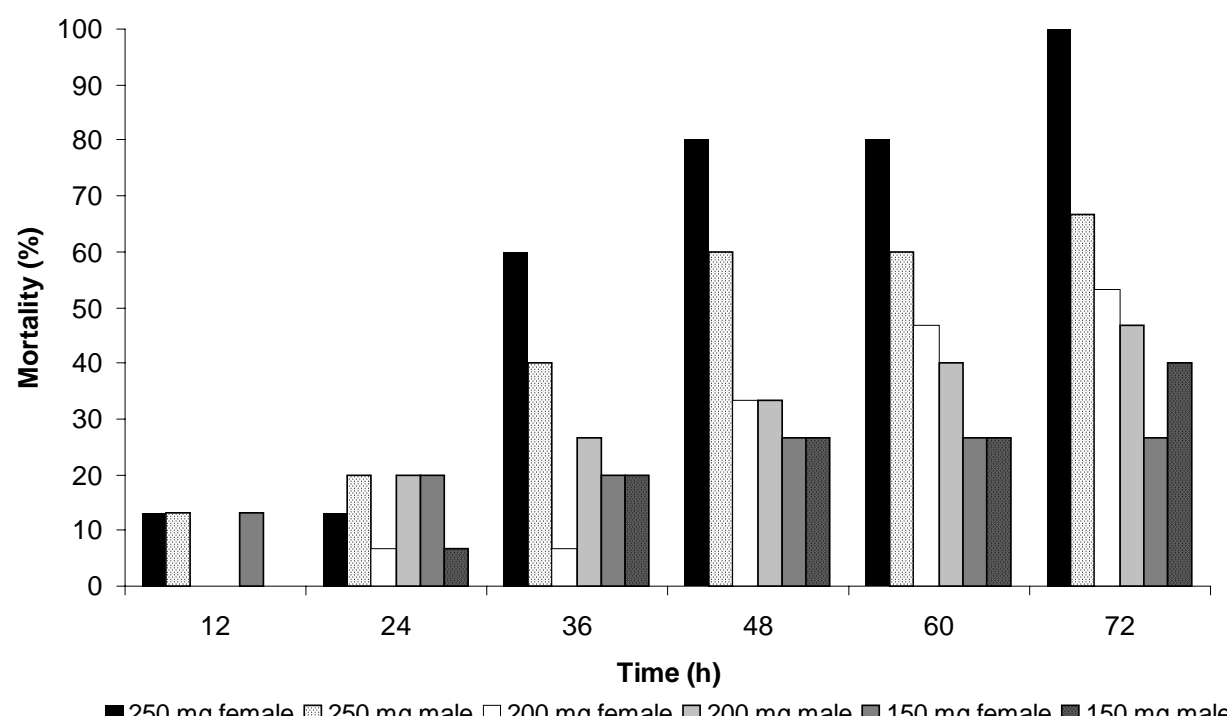

Fig. 1: Lutzomyia longipalpis mortality when exposed to extracts of the timbó Derris amazonica at different concentrations.

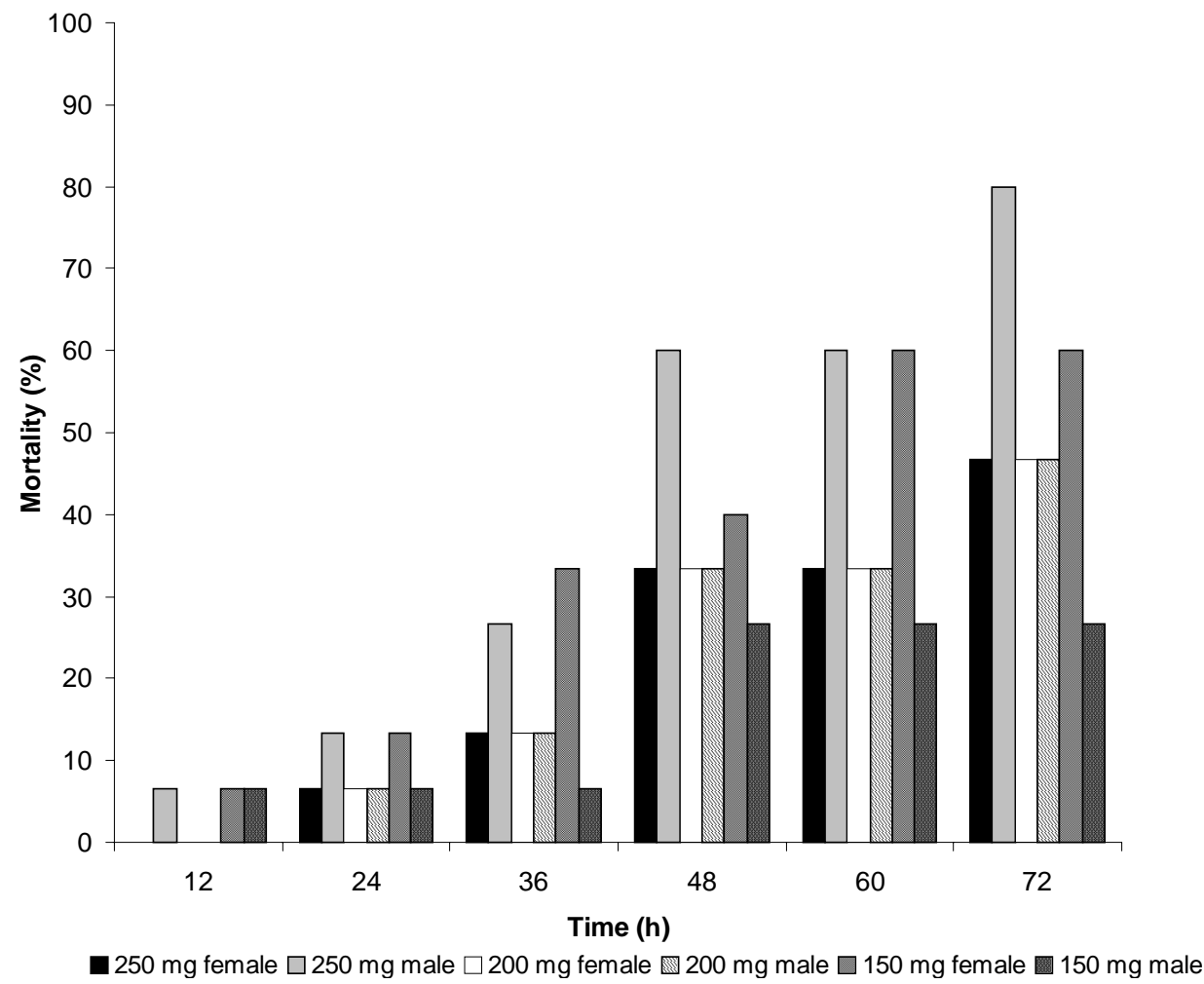

Fig. 2: Lutzomyia longipalpis mortality when exposed to extracts of the timbó Antonia ovata at different concentrations.

\section{REFERENCES}

Angely J 1985. Pesquisas sobre famílias brasileiras pouco conhecidas. Fam. Antoniaceae. J Botân 330: 2.

Aragão JA, Valle JR 1973. Ictiotoxicidade de timbós dos gêneros Serjania, Derris e Tephrosia. Ci Cult 25: 649.

Balandrin MF, Klocke JA, Wurtele ES, Bollinger WH 1985. Natural plant chemicals: sources of industrial and medicinal materials. Science 228: 1154-1160.

Bell EA, Fellows LE, Simmonds MSJ 1990. Natural products from plants for the control of insect pests. In E Hodgson, RJ Kuhr (eds), Safer Insecticides, Marcel Dekker, New York, p. 337-350.

Berman FW, Gerwick WH, Murray TF 1999. Antillatoxin and kalkitoxin, ichthyotoxins from the tropical cyanobacterium Lyngbya majuscula, induce distinct temporal patterns of NMDA receptor-mediated neurotoxicity. Toxicon 37: 16451648.

Braz Filho R, Gottlieb OR, Mourão AP 1975. A stilbene and two 
flavonones from Derris rariflora. Phytochemistry 14: 261.

Chacon JO 1973. O timbó (Rotenona) usado como inseticida e tóxico para peixes. Fortaleza, Brasil. Boletim Técnico, Dnocs, 31: 123-129.

Coats JR 1994. Risks from natural versus synthetic insecticides. Ann Rev Ent 39: 489-515.

Costa CNB, Carvalho LODM, Dutra S, Pimentel ES 1989. Uso de timbó urucu (Derris urucu) no controle do piolho (Haematopinus tuberculatus) em bubalinos. Boletim de Pesquisa 78, Ibama, Brasília.

Costa JP, Bélo M, Barbosa JC 1997. Efeitos de espécies de timbós (Derris spp.: Fabaceae) em populações de Musca domestica L. An Soc Entomol Brasil 26: 163-168.

Falcão AL, Falcão AR, Pinto CT, Gontijo CMF, Falqueto A 1991. Effect of deltamethrin spraying on the sand fly populations in a focus of American cutaneous leishmaniasis. Mem Inst Oswaldo Cruz 86: 399-404.

Farabee WC 1918. The Central Arawak, Anthropological Publications of the University Museum, No. 9, Philadelphia, 18 pp.

Farnsworth NR 1966. Biological and photochemical screening of plants. J Pharm Sci 55: 225-276.

Funasa 2001. Boletim eletrônico epidemiológico 1(1): p. 7. www.funasa.gov.br/pub/boletim_eletronico_epi

Grainge M, Ahmed S 1988. Handbook of Plants with Pest-control Properties, Wiley, New York, 470 pp.

Gutman M, Singer TP, Beinert H, Casida JE 1970. Reactions sites of rotenone, piericidin A, and amytal in relation to the nonheme iron components of NADH dehydrogenase. Proc Natl Acad Sci USA 65: 763-770.

Heal RE, Rogers EF, Wallace RT, Starnes O 1950. A survey of plants for insecticidal activity. Llodyia 13: 89-162.

Igarashi T, Aritake S, Yasumoto T 1998. Biological activities of prymnesin-2 isolated from a red tide alga Prymnesium parvum. Nat Toxins 6: 35-41.

Igarashi T, Aritake S, Yasumoto T 1999. Mechanisms underlying the hemolytic and ichthyotoxic activities of maitotoxin. Nat Toxins 7: 71-79.

Johnson BM, Stein RA, Carline RF 1988. Use of a quadrat rotenone technique and bioenergetics modeling to evaluate prey availability to stocked piscivores. Am Fisheries Soc 117: 127-141.

Klocke JA 1989. Plant compounds as source and models of insect-control agents. In K Hostettmann, Economical and Medicinal Plant Research, Academic Press, London, p. 103-144.

Lainson R, Shaw JJ, Ryan L, Ribeiro RSM, Silveira FT 1985. Leishmaniasis in Brazil. XXI - Visceral leishmaniasis in the Amazon Region and further observations on the role of Lutzomyia longipalpis (Lutz \& Neiva, 1912) as the vector. Trans $R$ Soc Trop Med Hyg 79: 223-226.

López-Antuñano FJ 1992. Epidemiology and control of malaria and other arthropod born diseases. Mem Inst Oswaldo Cruz. 87 (Suppl. III): 105-114.

Luitgards-Moura JF, Castellón EG, Rosa-Freitas MG 2000. Aspects related to productivity for four generations of a Lutzomyia longipalpis laboratory colony. Mem Inst Oswaldo Cruz 95: 251-257.

Mahato SB, Ganguli AN, Sahu NP 1982. Steroid saponins. Phytochemistry 21: 959-978.

Marzochi MCA, Marzochi KBF 1994. Tegumentary and vis- ceral leishmaniases in Brazil - emerging anthropozoonosis and possibilities for their control. Cad Saúde Publ 10 (Supl. 2): $359-375$

McCoy LF Jr, Martin DF 1977. The influence of Gomphosphaeria aponina on the growth of Gymnodinium breve and the effect of aponin on the ichthyotoxicity of Gymnodinium breve. Chem Biol Interact 17: 17-24.

McPhail K, Davies-Coleman MT, Coetzee P 1998. A new furanosesterterpene from the South African nudibranch Hypselodoris capensis a dictyoceratida sponge. J Nat Prod 61: 961-964.

Miles DH, Ly AM, Chittawong V, de la Cruz AA, Gomez ED 1989. Toxicants from mangrove plants VI. Heritonin, a new piscicide from the mangrove plant Heritiera littoralis. $J$ Nat Prod 52: 896-898.

Ministério das Minas e Energia 1975. Projeto Radambrasil. Roraima: Geomorfologia, Pedologia, Vegetação e Uso Potencial da Terra, Rio de Janeiro, 428 pp.

Moretti C, Grenand P 1982. Les nivrées ou plantes ichthyotoxiques de la Guyane Française. J Ethnopharm 6: 139-160.

Mors WB, Nascimento MC, Valle JR, Aragão JA 1973. Ichthyotoxic activity of plants of the genus Derris and compounds isolated there from. Ci Cult 25: 647-648.

Pereira GFM, Fonseca HHR 1994. Leishmaniose tegumentar americana: epidemiologia e controle. Rev Soc Bras Medic Trop 27 (Supl. III): 45-50.

Quinnel RJ, Dye C 1994. An experimental study of peridomestic distribution of Lutzomyia longipalpis (Diptera: Psychodidae). Bull Ent Research 84: 379-382.

Raws RL 1986. Experts probe issues, chemistry of light-activated pesticides. Chem Eng News Sep 22: 2124.

Reinertaen H, Jensen A, Koksvik JI, Olsen Y 1987. Effects of fish removal on the limnetic ecosystem of an eutrophic lake. J Fish Aquat Sci 47: 166-173.

Russel RM, Robertson JL, Savin ME 1977. POLO: a new computer program for probit analysis. Bull Ent Soc Am 23: 209213.

Smith AC 1939. Notes on a collection of plants from British Guiana. Lloydia 2: 161-218.

Sukamar K, Perch MJ, Boobar LR 1991. Botanical derivates in mosquito control: a review. J Am Mosq Control Assoc 7: 210-237.

Teixeira JR, Lapa AJ, Souccar C, Valle JR 1984. Timbós: ichthyotoxic plants used by Brazilian Indians. J Ethnopharmacol 10: 311-318.

Van Wagenen BC, Huddleston J, Cardellina JH 1988. Native American food and medicinal plants, 8. Water-soluble constituents of Lomatium dissectum. J Nat Prod 51: 136-141.

Xavier HS 1975. Serjanosídeos A, B e C Saponinas triterpenoidais da Serjania caracasana (Jacq) Wild, MSc Thesis, UFRJ, Rio de Janeiro, $133 \mathrm{pp}$.

White GB 1991. Chemical control of disease vectors: quel avenir? Ann Soc Belg Méd Trop 71: 17.

WHO-World Health Organization 1997. Vector Control: Methods for Use by Individuals and Communities. Prepared by Jan A Rozendaal, 412 pp.

Yoshida HA, Toscano NC 1994. Comparative effects of selected natural insecticides on Heliothis virescens (Lepidoptera: Noctuidae) larvae. J Econ Entomol 87: 305-310. 